\title{
MAGMARANA: A poesia de Magma em Sagarana, de Guimarães Rosa
}

\author{
Zama Caixeta Nascentes
}

\author{
Professor de Língua Portuguesa e Literatura Brasileira do CEFET-PR, unidade de \\ Curitiba
}

Especialista: Língua Portuguesa (FFCL - Patos de Minas-MG) e Filosofia Política (UFPR)

\begin{abstract}
RESUMO: Duas serão as nossas ocupações no artigo: 1) demonstrar a permanência do Guimarães-poeta de Magma, 1936, na criação da fauna e flora de Sagarana, 1945; 2) explicitar a importância dos trechos paisagísticos para a organicidade dos contos, não podendo ser considerados interrupções, cortes ou entidades de menor valor. São Marcos merecerá uma atenção maior, por deter-se mais na paisagem. Estaremos fazendo referência a outras narrativas do primeiro livro de prosa de Guimarães à medida que encontrarmos nelas exemplos elucidativos. Analisaremos poemas de Magma, apontando como procedimentos poéticos empregados aí pelo autor aparecem de igual modo em Sagarana.
\end{abstract}

PALAVRAS-CHAVE: poesia, prosa, associação semântica, estilística fônica, unidade, métrica, escansão.

\section{INTRODUÇÃO}

Nosso contato com a obra de Guimarães Rosa nos levou a propor, em 1996, quando do nosso ingresso no CEFET-PR em regime de Dedicação Exclusiva, este estudo temático: o problema dos contrários. Ao finalizá-lo, verificamos ser isso pertinente para apenas parte da ficção rosiana. Nossa expectativa filosofante foi baldada e Sagarana, excetuando A hora e a vez de Augusto Matraga e Duelo, era, dentre os livros do autor mineiro, o que mais nos desconcertava: líamos, bislíamos, treslíamos e desencontrávamos os contrários!

Mas, "no meio do caminho tinha uma pedra / tinha uma pedra no meio do caminho" (01) e a pedra chamava-se Machado de Assis. Gritava-nos: "A pedra, ó José, a pedra / Resiste, ó José" (02). A pedra? Os contrários, o filosofês, o mitologês, instituídos como chave para ganharmos o reino dos seus significados, ó Guima! E com machado desbastamos o cipoal teórico que empoava a rosa da língua na prosa do carreiro, "coisa de por si engraçada" (03). Resistimos.

De lá (1996) pra cá (2000), trabalhamos Sagarana, a cada semestre, com nossos alunos concluintes do $2^{\circ}$ grau, e agora do Ensino Médio. Metodologicamente, impúnhamos a nós a exigência de variar de contos de uma turma para outra, montar avaliações diferenciadas a cada novo semestre. Com isso, obrigávamo-nos a constantes releituras da obra, a qual nos parecia sempre original, como se nunca a tivéssemos lido. A riqueza da construção das narrativas, aprendida no convívio com os contos machadianos, patenteava-se, abrindo clareiras de significados onde até então só existira nosso tropeço.

Publicado só em 1997, Magma nos permitiu fluir para novos ainda ocultos trilhos de Sagarana. Sempre partimos, com nossos alunos, do princípio de que nada no texto literário é aleatório. Tal determinismo estético era posto em xeque quando nos deparávamos com os parágrafos-painéis da obra, pedreiras para noviços leitores. A 
amolecê-las, ajudaram-nos as águas da serra do fervilhante Magma. Nas páginas seguintes apresentaremos uma leitura de Sagarana sob a influência da magna poesia de 1936.

\section{1- A BELA E BÉLICA PAISAGEM POÉTICA DE SÃO MARCOS}

A primeira das "interrupções" da narrativa para construir uma paisagem textual em São Marcos encontra-se no parágrafo clarificador do objetivo da viagem empreendida pelo narrador: observar a paisagem do meio do mato, o que já dá idéia da importância desse tema dentro do conto. Vale a pena transcrevê-lo já de saída:

"E levava boa matalotagem (...) Mas cumpria com a lista, porque eu não podia deixar o povo saber que eu entrava no mato, e lá passava o dia inteiro, só para ver uma mudinha de cambuí a medrar da terra de-dentro de um buraco no tronco de um camboatã; para assistir à carga frontal das formigas-cabaças contra a pelugem farpada e eletrificada de uma tatarana lança-chamas; para namorar o namoro dos guaxes, pousados nos ramos compridos da aroeira; para saber ao certo se o meu-xará joão-de-barro fecharia mesmo a sua olaria, guardando o descanso domingueiro; para apostar sozinho, no concurso de saltoà-vara entre os gafanhotos verdes e os gafanhões cinzentos; para estudar o treino de concentração do jaburu acromegálico; e para rir-me, à glória das aranhas-d'água, que vão corre-correndo, pernilongando sobre a casca de água do poço, pensando que aquilo é mesmo chão para se andar em cima." (04)

Como se vê, o objetivo da viagem do narrador é assistir, para usarmos um de seus verbos, ao espetáculo do mundo animal (bombardeio das formigas-cabaças; namoro dos guaxes; trabalho do joão-de-barro; concurso dos gafanhotos; treino do jaburu; pernilongamentos das aranhas-d'água) e vegetal (medrança da mudinha de cambuí; percepção da água como sendo chão, por parte das aranhas, e tronco, efetuada pelo narrador mediante o sintagma nominal "a casca de água"). Logo, a descrição, que poderia ser tomada como interrupção do enredo iniciado em "E eu levava boa matalotagem", deixa de ser interrupção, passando a constituir etapa integrante e necessária ao conto. Para tanto, basta pensarmos no papel fundamental desempenhado pelos elementos da fauna e flora no clímax: a perda da visão de Izé em conseqüência do feitiço feito pelo negro Mangolô.

Os trechos paisagísticos devem merecer do leitor a mesma atenção daqueles voltados aos casos de feitiçaria, os quais compõem, junto com a narrativa central, a polarização crença-dúvida na existência de feitiços, verdadeiro "leit-motiv" do conto. A impressão de corte é sugerida pelo narrador, ainda na mesma página, quando usa o seguinte procedimento coesivo: "Mas, como eu contava ainda há pouco, eram sete horas, e eu ia indo pela estrada, com espingarda, matula, manhã bonita e tudo". Outra leitura desfaz essa idéia inicial, dando a dimensão da importância da paisagem no conto. 
Merece ser discutida a ênfase dada ao sentido da visão. É muito mais pela visão que por qualquer outro sentido que captamos paisagens, embora em SM o texto trabalhe também com referentes olfativos - claramente exalado do neologismo "alhum" para expressar o "bodum" do pau-d'alho - e auditivos. Por vezes, fundem-se no conto, como no clímax, "Meus olhos o ouvem" (05). A perda de Izé é perda do sentido da visão e é nos olhos que ele sentirá a força da feitiçaria da qual descria. Assim, ver assume outra conotação: empatia, a capacidade de depor sua visão de mundo e assestar a lente do outro. Ora, é precisamente para isso que Izé é cego; logo, sua cegueira orgânica metaforiza sua cegueira epistemológica, pois menospreza a verdade da cultura popular, para a qual o feitiço é um fenômeno tão positivo (real, existente, crível) quanto os fenômenos naturais.

Exposta a importância da descrição para a unidade e a temática do conto, deslindaremos agora o seu teor poético. Para tanto, trabalharemos com processos que, se não exclusivos da poesia, são nela mais freqüentes: associação semântica (06), exploração do estrato fônico, métrica e rima .

A associação semântica pode ser vista na caracterização das formigas. Há um sugeridor inicial, "carga frontal", funcionando como núcleo semântico (guerra, batalha) motivador da escolha lexical subseqüente. Teremos assim o inimigo, "tatarana lança-chamas", cujo nome, "lança-chamas", expressa sua belicosidade e artilharia, e que possui "pelugem farpada e eletrificada". "Farpada" reforça a hostilidade, a fronteira rígida existente entre os dois combatentes, enquanto que "eletrificada" reitera o subjacente sintagma comparativo "como uma cerca de arame" (já sugerido pelo "farpado"), posto ser comum a eletrificação das cercas de arame (liso ou farpado) para conter avanços do inimigo. Sendo "eletrificada", não lhe é inusitado o atributo de lançar chamas, dada a cadeia causal: eletrificada $\rightarrow$ curto-circuito $\rightarrow$ incêndio $\rightarrow$ chamas.

Aliás, para irmos já ao Magma, a eletricidade natural, dispensadora de barragens e redes de transmissão, já havia incandescido os fios da imaginação do poeta Guimarães produzindo-lhe lumes em $O$ Caboclo d'Água

" Na água parada

entre as moitas de saras e canaranas,

o puraquê tem pensamentos

de dois mil volts." (07)

em que, curiosamente, vemos, sobre o peixe, a projeção do processo de criação artística vivido pelo autor. Afinal, "pensamentos de dois mil volts" teve-os Guimarães para humanizar o puraquê, atribuindo-lhe a racionalidade (08) vista no boi Rodapião de Conversa de bois, mediante a simples substituição do complemento de ter, quebrando a expectativa do leitor, cujo conhecimento de mundo o predispunha a combinar "dois mil volts" com o elemento descarga e_não com "pensamentos". Que choque levamos!

Construir parágrafo descritivo a partir do campo semântico guerra/batalha, dos quais emergem verdadeiras plantas e arbustos beligerantes, é o procedimento empregado por Guimarães para taperizar a casa de Sarapalha. Julgamos ser esse o melhor momento 
para transcrevê-lo, pois se presta a ilustrar o processo poético em foco, empregado em SM. Destacaremos os vocábulos que carregam em si a noção de luta:

"Aí a beldroega, em carreirinha indiscreta - ora-pronobis! ora-pro-nobis! - apontou caules ruivos no baixo das cercas das hortas, e, talo a talo, avançou. Mas o cabeça-de-boi e o capim-mulambo, já donos da rua, tangeram-na de volta; e nem pôde recuar, a coitadinha rasteira, porque no quintal os joás estavam brigando com o espinho-agulha e com o gervão em flor. E, atrás da maria-preta e da vassourinha, vinham urgentes, do campo - oi-ai! - o amor-de-negro, com os tridentes das folhas, e fileiras completas, colunas espertas, do rijo assa-peixe." (09)

Outros signos contribuem para a criação da atmosfera de trincheira do parágrafo. Como entender a católica invocação litúrgica latina "ora-pro-nobis! ora-pro-nobis!" se não a associarmos a um réquiem (evocado no emprego do verbo tanger, desencadeador da série sino/morte/finados, dobrar/planger, a trazer à consciência do leitor a dor das vítimas da malária ali do arraial e a pungência da solidão enfrentada agora pelos dois primos, aspectos centrais no conto. Logo, a invocação se presta também à sutura do texto, não à soltura, como poderia dar a entender àqueles leitores sequiosos apenas dos acontecimentos) antecipado da derrotada beldroega, que sequer pôde recuar? Se tomarmos essa via dolorosa da "coitadinha" da beldroega, encontraremos na seqüência do parágrafo o seu cortejo fúnebre, "gervão em flor"; "maria-preta"; "ai"; "amor-denegro", por serem flor, choro ("ai") e luto ("preta", "negro") elementos caracterizadores da morte, e a morte é uma consequiência lógica da luta e da batalha: todas essas idéias vemos estrategicamente aliadas nesse parágrafo de Sarapalha. Para finalizar a poesia do trecho, o esperto autor, talvez para dar aos seus leitores a poesia de Magma, cuja publicação sempre recusou, completa-o com três redondilhas menores:

fi/lei/ras/ com/ple/tas (desconsiderando-se o "e" inicial),

co/lu/nas/ es/per/tas,

do/ ri/jo a/ssa/pei/xe.

Tamanha ordem na metrificação nos diz da própria disciplina do batalhão em marcha para conquistar a casa e edificar a tapera, já que é possível edificar taperas depois de Augusto dos Anjos ter construído o "operário das ruínas" (10), com todo o estranhamento no plano sintático produzido pela mútua exclusão de "operário" e "ruínas".

Do ponto de vista da unidade do conto, a batalha entre ervas daninhas é uma alusão à grande erva daninha de cuja extirpação, mediante a palavra, ocupa-se o Primo Argemiro: o terrível segredo de ter desejado um dia a esposa do primo: "É preciso perguntar-lhe alguma coisa (...) E Primo Argemiro tem de puxar qualquer conversa" (11). Ora, ao extirpá-la, despovoa das boas recordações o Primo Ribeiro; simbolicamente, transforma-lhe em tapera a vida afetiva, arruína-lhe o coração, aguilhoando-o com o "espinho-agulha" do ciúme e da traição. Paradoxalmente, a 
mesma palavra que cura o Primo Argemiro fere o Primo Ribeiro, para referirmo-nos a um dos temas recorrentes na obra do Rosa: o poder da palavra.

Tendo falado em métrica no Sarapalha, acertadamente é a hora e a vez de inserirmos em nosso estudo o conto Minha gente, pois nele há outro exemplo bem acabado de metrificação, equiparável ao antológico "As ancas balançam, e as vagas de dorsos, das vacas e touros...", de $O$ burrinho pedrês, estudado, dentre outros críticos, por Ângela Vaz Leão (12).

"Mas não era curta a viagem das Três Barras ao Saco-doSumidouro, tanto que houve tempo para pensar e sentir. Amplos campos navegantes; depois, o mato montano, onde pia o zabelê. Por aí, tive cansaço e vergonha de tudo o que antes eu dissera e fizera, e foram notáveis os meus pensamentos. O pio do zabelê é escandido e gemido. A estrada do amor, a gente já está mesmo nela, desde que não pergunte por direção nem destino. $\mathrm{E}$ a casa do amor em cuja porta não se chama e não se espera - fica um pouco adiante.

- Eco! Eco! - gritavam os tucanos verdes.

- Óco! Óco! - ralhavam os tucano-açus". (13)

Como em tantos outros contos de Sagarana, estamos diante do tema da viagem. Viagens na obra de Guimarães sempre são portadoras de outros significados, via de regra simbolizando uma mudança de postura interna do sujeito, não o mero

deslocamento espacial. Além dessa conotação psicológica, o motivo da viagem se presta ao espraiamento da narrativa pela paisagem: à medida que o caminho é percorrido, $o$ texto desloca-se para a vegetação, fauna, relevo, criando, pela linguagem poética já experimentada em Magma, matizes, sons, cheiros, possibilitando ao leitor uma experiência total em que o objeto estético, o texto, é captado não só pelo intelecto, mas também pelos sentidos. Torna-se significativa assim a afirmação do narrador, "houve tempo para pensar e sentir". Posto isso, passemos à métrica, razão de nossa viagem pelo Minha gente.

Ela não se encontra em todo o parágrafo, mas espalhada nalgumas frases, uma delas a segunda, "Amplos campos navegantes; depois, o mato montano, onde pia o zabelê", que, após escansão, ver-se-á tratar de redondilhas maiores:

"Am/plos/ cam/pos/ na/ve/gan/tes;

de/pois,/ o/ ma/to/ mon/ta/no,

on/de/ pi/a o/za/be/lê/

A métrica (motivadora da escolha de "zabelê" dentre as palavras existentes no idioma para nomear o pássaro - jaó, juó, macucau, macucauá - pois qualquer uma delas quebraria a seqüência de redondilhas maiores iniciadas pelo primeiro segmento frasal) não é o único elemento a poetizar a frase. Atentemos para o valor expressivo das vogais 
nasais em "amplos campos navegantes" e "montano", que desencadeiam no inconsciente lingüístico do leitor a melancolia (14) e nostalgia do zabelê, explicitadas logo a seguir, "o pio do zabelê é escandido e gemido". Curiosamente, o dicionário registra a variante "zambelê", que asseguraria tanto a métrica trabalhada como a seletividade das vogais. Mas, dai a Guimarães o que é de Guimarães... Por fim, encontram-se também na frase duas aliterações, /m/ e /t/, "mato montano" e, nesse mesmo sintagma, a rima toante $\mathrm{a} / \mathrm{o}$.

A consciência do trabalho com a métrica aparece na frase "O pio do zabelê é escandido e gemido". A exemplo da eletrificação dos pensamentos do puraquê num dos poemas de Magma, e do pica-pau poeta a retocar versos em Ritmos Selvagens, também Magma (do qual falaremos adiante), ocorre aqui a projeção num elemento da natureza do próprio processo da criação artística. $\mathrm{O}$ autor vem trabalhando sistematicamente com heptassílabos e agora transfere a operação da escansão para o pio do zabelê, "pio escandido". O que ele faz aqui com a problemática crucial da poesia moderna, debatida epistolarmente entre Manuel Bandeira e Mário de Andrade (15): como explicar o ritmo na poesia? Os poetas modernos reconhecem a importância do ritmo, tanto assim que Drummond considera-o, em sua apresentação da Antologia Poética, o elemento essencial da poesia. Mas o que o cria? Não é a métrica, claro, mas com ela pelo menos fica facílimo dar a razão da sua existência. Que poética pode se deduzir da ornitológica frase rosiana "o pio do zabelê é escandido e gemido"? Preferimos ficar com a hipótese de que o autor mobiliza aquele adjetivo para o zambelê porque tinha consciência da métrica em suas frases e queria do leitor um ouvido capaz de captá-la; para tanto soltou um pio-pista. Foi ouvido? Banquemos nós agora o zabelê e façamos a escansão da frase. Não há pontuação marcando a cesura, mas lá estão duas redondilhas maiores:

$\mathrm{O} / \mathrm{pi} / \mathrm{o} / \mathrm{do} / \mathrm{za} / \mathrm{be} / \mathrm{lê} /$

é/ es/can/di/do e/ ge/mi/do

Do parágrafo, outro trecho escandidamente construído é o seguinte, contendo duas redondilhas menores, um alexandrino e, finalizando o período, outra redondilha maior:

A es/tra/da/ do a/mor/

$\mathrm{E} \mathrm{a} / \mathrm{ca} / \mathrm{sa} / \mathrm{do}$ a/mor/

$\mathrm{Em} / \mathrm{cu} / \mathrm{ja} / \mathrm{por} / \mathrm{ta} /$ não/ se/ cha/ ma e/ não/ se es/pe/ra

$\mathrm{Fi} / \mathrm{ca}$ um/ pou/co/ mais/ a/dian/te

Para encerrar, o prosador-poeta cria nada mais nada menos que dois alexandrinos, decorrentes ou causadores do paralelismo sintático?

E/co!/ E/co!/ - gri/ta/vam/ os/ tu/ca/nos/ ver/des

Ó/co!/ Ó/co! - ra/lha/vam/ os/ tu/ca/no-a/çus/

Se líamos antes o pio do zabelê numa perspectiva metatextual, o "pio escandido" como pista para o leitor ouvir o ritmo da frase e confirmá-lo pela técnica exegética da 
escansão, tomamos agora os gritos dos tucanos verdes como a intensificação desse alerta do poeta-contista. Se depois de tudo isso, somado à simetria sintática das duas últimas frases visualmente notada sem exigir análises mais profundas, o leitor não ouviu, se nada ecoou nele apesar dos constantes ecos (repetições) métricos no parágrafo (e nesse caso estaríamos diante de um leitor oco, obcecado pelo enredozinho), esgotouse a paciência do narrador e tal impaciência é projetada na irritação dos tucano-açus, "ralhavam os tucano-açus". O trecho não fica nada a dever ao já antológico "as ancas balançam" de $O$ burrinho pedrês.

Após tantas viagens pelos ritmados parágrafos sagarânicos, é hora de voltarmos a outros exemplos de associação semântica em São Marcos. Vamos a um parágrafo em que a natureza é erogenizada. Foi estrategicamente inserido após a Renda da Yara, local onde "convém meditar sobre as belezas da castidade, reconhecer a precariedade dos gozos da matéria" (16). Que belíssimo contraponto paisagístico!

"Primeiro, o 'Vênusberg' - onde impera a perpendicularidade excessiva de um jequitibá-vermelho, empenujado de liquens e roliço de fuste, que vai liso até vinte metros de altitude, para então reunir, em raqueta melhor que em guarda-chuva, os seus quadrangulares ramos. Tudo aqui manda pecar e peca - desde a ciganado-mato e a mucuna, cipós libidinosos, de flores poliandras, até os cogumelos cinzentos, de aspirações muito terrenas, e a erótica catuaba, cujas folhas, por mais amarrotadas que sejam, sempre voltam, bruscas, a se retesar. Vou indo, vou indo, porque tenho pressa, mas ainda hei de mandar levantar aqui uma estatueta e um altar a Pã" (17).

O curioso no parágrafo é o fato de ele abrir-se com o exegético (já que é a chave para compreender o eixo semântico erotismo/sensualidade sobre o qual gravita todo o resto) "Vênusberg", imantador dos significados do trecho. Não é à toa aquele "primeiro, o "Vênusberg'", pois ele está topicalizando, destacando-o como o elemento fundante do significado dos signos dispostos a seguir. Não se trata da primeira das três clareiras nomeadas um parágrafo antes, mas sim de metalinguagem, um modo de reiterar a ficcionalidade, chamando para o modo mesmo de construção do texto e não para um referente externo a ele, a paisagem local. Com essa introdução, a narrativa volta-se para si, um discurso sobre o discurso.

O nome Vênusberg é motivado, não arbitrário, para lembrarmos um dos brinquedos prediletos do Rosa com a linguagem: é formado da justaposição de Vênus e berg. Ora, em alemão, "der Berg" é exatamente um substantivo masculino que significa monte, montanha. Portanto, a tradução literal é monte de Vênus. Mesmo que o leitor não decifre a etimologia de Vênusberg, Vênus por si basta para evocar sensualidade. Nós invocamos estes versos de Sonho de uma Tarde de Inverno, do Magma: "Um monge / (...) / deixou errar seus dedos e seus sonhos, / e fez crescer, no jalde de um cibório, / o relevo de uma Vênus / com um cupido ao colo..." (18). Do poema, Guimarães aproveitou ainda o ambiente convidativo à leitura de cavaleiras novelas, presente em SM no local chamado Rendas de Yara. Vejamos agora como o desenvolvimento do parágrafo não perderá de vista a semântica contida no nome "Vênusberg". 
Temos já de saída liquens abraçando o jequitibá-vermelho. Sua cor, vermelho, está ligada à sexualidade, por ser cor forte, "quente". Não sejamos precipitados em ver no jequitibá um símbolo fálico, fiquemos apenas com a sua sugestiva penugem, "empenujado de liquens", suficiente para indicar uma adolescente prontidão (pêlos) para a sexualidade. Agora, já diante do "roliço de fuste", não se pode mais resistir à tentação. Afinal, o narrador diz logo a seguir "Tudo aqui manda pecar e peca". Então, não há como ser puritano na análise! A tentação é dar uma guinada freudiana, pois "fuste" significa precisamente "vara, bastão, haste". E o que dizer de "roliço", a evocar gr(l)andes arredondadas formas? E se voltarmos ao vermelho do jequitibá, que outro atributo anatômico se nos impõe senão a genitalidade do varão (casualmente mistura de vara e bastão a fustigar o vênusberg provocando pudicos vermilhidões...)? Àqueles que resistem a penetrar (!) nesse campo de significações, socorre-lhes o narrador, "Tudo aqui manda pecar e peca". Segue-se a nomeação das sacerdotisas desse "templo" de Vênus, "a cigana-do-mato e a mucuna". Facilmente associamos "cigana" à sensualidade, basta lembrarmos da lendária sedutora Carmen, imortalizada pela ópera homônima de Bizet. No âmbito da obra do Rosa, saltamos para Zingaresca, o último conto do seu último livro, Tutaméia, no qual a zingaresca sensualidade recai sobre o masculino, o cigano Vai-e-Volta que, literalmente, vira a cabeça da mulher do fazendeiro Zepaz, obrigando-o a deixar a paz do seu nome para castigar a mulher: "a mulher de Zepaz, com o cigano Vai-e-Volta, se estiveram, os dois debaixo de um mantão... Zepaz, sim? ouviu, de vermelho preteou, emboca em casa, surrando já a mulher, no pé da afronta, até o diabo levantar o braço" (19). Depois da "cigana-do-mato" temos a "mucuna". Ora, uma das determinações das vagens da mucuna é "têm um revestimento piloso que causa prurido na pele de quem lhes toca". Há como negar a presença desses traços semânticos no campo fundado a partir do nome Vênusberg? "Revestimento piloso" está para o "empenujado dos liquens" e a pilosidade é precisamente uma das marcas da adolescência; "que causa prurido", coceira, inquietação, desejo, tesão, "na pele de quem lhes toca"!!! E quem, no Vênusberg, toca tão urtigantes leguminosas senão os "cipós libidinosos", de libido mesmo, conceito central da Psicanálise do Dr. Freud e que designa a energia sexual? Com certeza pecam. Em seguida vêm "os cogumelos cinzentos, de aspirações mui terrenas": quem há de ter "aspirações celestiais, ascéticas" no monte de Vênus? Tudo é pecado! E, para o textual gozo final, "a erótica catuaba, cujas folhas, por mais amarrotadas que sejam, sempre voltam, bruscas, a se retesar". O determinante "erótica" já fala por si; afinal a catuaba é conhecida nacionalmente por capacitar a subida ao Vênusberg... O problema passa a ser o seguinte: o que teria amarrotado as folhas da catuaba? Parece-nos caber uma só resposta: o pecado grassante no monte! E por fim, vejam a sensualidade (seria muita ingenuidade dizer sensibilidade a essas horas!) do Guimarães ao nomear a ação das folhas da catuaba: "retesar", literalmente "ficar teso novamente". De fato, a única saída digna da análise desse parágrafo é assumir a fuga do narrador: "Vou indo, vou indo", senão resvalamos e pecamos contra o "canto e plumagem" (20) da linguagem acadêmica! Preferimos resvalar para dentro do Magma, no poema Hierograma no qual já aparece uma natureza erogenizada ("No jardim pagão, / entre os panos de púrpura de uma fúcsia / poliandra, / oito estames preguiçosos / namoram um pistilo voluptuoso...") (21), dando mostras da continuidade, não da ruptura entre Magma e Sagarana.

"Vou indo, vou indo" e Izé chega assim às lagoas de SM. Nesse momento do conto, lentifica-se a ação e os propósitos paisagísticos do autor levam-no a elaboradíssimas pinturas. O leitor atento só ao enredo mergulha na sonolência. Todavia, acelera-se a 
poesia do texto. Não detalharemos a análise desses trechos, para não nos estendermos muito. Um breve comentário segue-se abaixo.

Do ponto de vista do trabalho com os campos semânticos, elemento poético que estamos analisando, temos verdadeiras preciosidades: árvores tornam-se "Puro Egito"; o pouso de patos bravos é construído a partir da mobilização do léxico extraído da navegação fluvial e marítima e até aérea, pois temos o neologismo "aquatiza" a partir de "aterrissa"; a lagoa corporifica-se, adquirindo rabo (posto estar povoada de "gadinho de asa" (22) dotado de rabo) e maternais mãos nas quais "o marrequinho pousa tão próprio, aninhado e rodado, que a lagoa é que parece uma palma de mão, lisa e maternal, a conduzi-lo"; formigas viram o "povinho miúdo", (evocando o "gadinho" de Duelo), tanto assim que são "simpáticas", possuem deus; a contradição humana de Augusto Matraga, Turíbio Todo, Cassiano Gomes e Timpim/Vinte-e-Um projeta-se sobre o louva-a-deus, "Ele está sempre rezando, rezando de mãos postas, com punhais cruzados. Mas, no domingo (dia santificado) passado (...) comeu o companheiro" (23). Tal modo de criar um louva-a-deus em São Marcos encontra-se no poema Oração, ("O louvadeus, ereto, num caule de junquilho, / reza, de mãos postas, com punhais cruzados, / como um bandido calabrês..." - 24) contido na série Poemas de Magma, o que não deixa dúvidas sobre o vínculo entre Magma e Sagarana, e, de igual modo, com outra obra do Rosa, Estas Estórias, pois nessa mesma série temos o poema Paisagem, ("A cascavel chocalha na moita, anunciando, / grátis, / um destino certo..." - 25), bote já armado para o conto Bicho Mau, história deixada fora de Sagarana e incluída em Estas Estórias. Talvez seja esta uma das razões pelas quais Guimarães nunca publicou Magma: para que, se sua prosa é poética tanto quanto sua poesia de 1936 ?

Anterior ao Vênusberg, outros parágrafos descritivos são encontrados e nos quais se nota também a sensibilidade poética do autor via exploração dos campos semânticos. Assim temos: a femininização das imbaúbas e seu idílio com o "cipó-braçadeira", semelhante aos "cipós libidinosos" do Vênusberg; a lagoa das Três-Águas é corporificada, "entremete o fino da cauda na floresta", a exemplo do que acontecerá com a outra lagoa onde pousam os patos; buritis constituem "arruados" e "famílias inteiras: buritis velhuscos, buritis-senhoras e buritis-meninos" (26), o último a puxar fluviais reminiscências de João Cabral de Melo Neto (27) e magnânimos ecos do poeta Guimarães em Luar da Mata, de Magma, habitado por "meninos passarinhos" (28).

\section{2- A METÁliCA PAISAGEM DE UM POEMA DE MAGMA}

Para dar cabo dos nossos propósitos, já é o momento de procedermos à análise de um dos poemas de Magma. Como vínhamos trabalhando com o processo da associação semântica, tomaremos, dos vários poemas dessa obra construídos a partir desse recurso, apenas um, Paisagem, por tratar do mesmo tema dos parágrafos antes destacados de Sagarana, paisagem. Ao transcrevê-lo, numeraremos os versos a fim de facilitar depois o comentário.

\section{PAISAGEM}

01- No quadrilátero do arrozal,

02- verde-aquarela, 
03- cortam-se em ângulos retos

04- canais azuis de água polida.

05- No ar de alumínio,

06- as libélulas verdes vão espetando

07- jóias faiscantes, broches de jade,

08- duplas cruzetas, lindos brinquedos,

09- nos alfinetes de sol.

10- Pairam suspensas, em vôo de caça,

11- horizontal,

12- e jogam, a golpes de tela metálica

13- das asas nervadas, reflexos de raios,

14- que hipnotizam as muriçocas tontas...

15- A libelinha pousa na ponta

16- do estilete de uma haste verde,

17- que faz arco (pronto!...)

18- e a leva direta à boca,

19- aberta e visguenta, de um sapo cinzento...

20- - Glu!... Muitas bolhas na escuma...

21- E as outras aeroplanam, assestando

22- para o submersível,

23- os grandes olhos redondos,

24- com quarenta mil lentes facetadas..." (29)

Começando pelo sugeridor inicial, "quadrilátero do arrozal", já teremos muito trabalho, posto ser bimembre, quadrilátero e arrozal, fundando no poema dois núcleos semânticos.

Se tomarmos o sentido lógico ligado à Geometria contido no primeiro, veremos a sua associação com ângulos retos / raios / arco dos versos 3, 13 e 17, respectivamente. Toda 
essa lição de Geometria encerra-se na última estrofe com o emergir da circunferência nos versos 20, "Muitas bolhas na escuma...", e 23, "os grandes olhos redondos".

Completa-se o poema-quadro ("quadrilátero"?) no qual o poeta-pintor cria a paisagem. A idéia de que o poema é um quadro aparece no verso 12, "tela", e está presente noutro texto de Magma, Verde, "Na lâmina azinhavrada / desta água estagnada, entre painéis de musgo", e numa passagem do discurso proferido por Guimarães em agradecimento à Academia Brasileira de Letras por tê-lo premiado pelo livro de poesia, na qual trata do que é para o autor a obra: "Pinta a sua tela, cega-se para ela e passa adiante" (30). O substantivo "tela" fala do constante fascínio exercido pela Pintura sobre a Literatura, do qual a Lira II da parte I de Marília de Dirceu é um quadro completo: "Pintam, Marília, os Poetas / A um menino vendado (...) Ora pois, eu vou formar-lhe / Um retrato mais perfeito" (31). E, para não nos restringirmos aos poetas, tomemos um exemplo de prosador moderno, Érico Veríssimo. Em prefácio de 1964 a Caminhos Cruzados, afirma o autor: "De resto, não devemos esquecer que Caminhos Cruzados é uma espécie de mural pintado com pistola automática e não uma tela trabalhada com pincéis de miniaturista" (32), o que já aparecera na boca de um de seus personagens de $O$ Arquipélago, tio Bicho, cujo papel dentro do romance é ser o crítico literário do personagem-romancista Floriano Cambará, (re)escritor da narrativa dentro da qual foi criado (33).

Anunciando já a circunferência, lá estavam, na estrofe anterior, estes versos: "... na ponta / do estilete de uma haste verde / que faz arco...", uma vez que uma circunferência surge da continuidade planejada da ação de "fazer arco". Além da reiteração da noção de Geometria, os versos criam uma sutil e belíssima metáfora do próprio fazer poético. Com efeito, da ponta da pena/lápis/caneta sai a paisagem, tema-título, concluída na última estrofe. As "quarenta mil lentes facetadas", último verso, dos "grandes olhos redondos" (verso 23) das outras libélulas são as quarenta mil lentes que nós, leitores de Magma, podemos "assestar" (verso 21) para o "multifacetado" poema do autor, no qual submergiremos na polissemia criada pelo cinzelamento da linguagem. A cada lente o poema terá um colorido diferente, tornando-se a aquarela do verso 2. Mal o julgamos deslindado e já nos emaranhamos novamente nos suspensos signos latejantes de significados.

Uma outra idéia mais vivaz parece ter se sobreposto à da Geometria. A nosso ver, tratase não mais da Geometria, mas sim da Geografia, evocando no autor mineiras reminiscências infantis mediante um outro sintagma nominal, ausente, mas nem por isso menos operante, "quadrilátero ferrífero", designador de toda a vasta região das Minas onde é abundante o ferro. É essa inconsciente representação a base da qual emerge um novo léxico a partir do verso 5, "no ar de alumínio", criando o terceiro núcleo semântico do poema, minerais.

Busquemos compreender agora o campo associativo formado por alumínio. Antes de mais nada, para voltarmos à analogia com a Pintura, o determinante de tela no verso 12 é "metálica", que se enfeixa também no tronco semântico "alumínio". Fundemse, pois, os referentes trabalhados por Guimarães. No alumínio-papel seu poema é uma Pintura gravada, razão pela qual emprega os verbos "cortam-se", "espetando" e o substantivo "estilete"/pena/caneta/lápis/tipo, instrumento(s) com o(s) qual(is) trabalha a gravação no metal-papel da tela-poema, para lembrarmos de Magma os Poemas (Madrigal gravado em laca): "Quando a borboleta coroou a flor amarela, / os lírios, em ângulo reto com seus caules,/ fizeram uma profunda saudação..." (34), de estreitíssimas 
conexões com o poema Paisagem e que aqui apenas gravamos sublinhandamente. Não é à toa o emprego de termos como "água polida", "jóias faiscantes", "reflexos de raios", pois é próprio de uma "tela metálica" brilhar muito. Se esquecermos "metálica", podemos "assestar" nossos "grandes olhos redondos" só para "tela" e submergiremos na "aquarela" do poema- $P(\mathrm{p})$ aisagem com seus tons amarelo, azul, cinzento, verde.

A propósito, o verde colore muitos outros poemas de Magma: A Iara ("Bem abaixo das colinas de ondas verdes (...) em vale côncavo, transparente e verde (...) Iara de olhos verdes muiraquitã"); Ritmos selvagens ("O pica-pau, vermelho e verde", animal-artista, pois, como noutros casos mostrados, temos o fenômeno da projeção, na natureza, do processo da criação poética. A projeção se dá nestes versos: "como um poeta, que desde a madrugada / vem fazendo o retoque dos seus versos"); Luar da Mata, II- Rapto ("a onça está parada, / apontando para cima olhos verdes de brasa": curiosamente, a mesma cor dos macunaímicos olhos da Iara, enriquecidos por um sinestésico cromatismo, pois "de brasa" põe nos nossos olhos outra cor, o vermelho); Elegia ("Estavas de pijama verde, / nas almofadas verdes (...) como um ídolo de jade"); Verde (propositalmente não é nomeada a cor, mas reaparece em "entre painéis de musgo" e nas "roupas de limo" vestidas pela antinarcísica feia rã quando mergulha no poço para quebrar o espelho); Poemas, Riqueza ("Veio ao meu quarto um besouro / de asas verdes e ouro, / e fez do meu quarto uma joalharia...". Como, diante desse joalheiro besouro, não pensar nas libélulas ourives de Paisagem?); Ironia ("Esses vaga-lumes, / abelhas sonâmbulas / de velinhas verdes"); Меи Papagaio ("Assim empoleirado, / de fraque verde com botões cor de ouro...); Ausência ("Entardece.../ Esfuziante e verde"); Gargalhada ("Mas olheite bem nos olhos, / belos como o veludo das lagartas verdes" em que temos o sinestésico veludo verde); por fim, o último e indispensável exemplo, Primavera na Serra, cujo título já evoca não só o verde mas uma verdadeira aquarela. É este o motivo do poema: uma árvore seca recebe, numa manhã, uma revoada de periquitos verdes, transformando-se "na paisagem que um pintor daltônico / pincelou no dorso de um camaleão", sendo o pintor daltônico o próprio poeta, dotado de uma sensibilidade incrível para lidar com a plasticidade das palavras, criando efeitos cromáticos nos seus poemas-tela de Magma (35).

Logo em seguida, no verso 6, lemos "as libélulas verdes vão espetando", com o verbo "espetar" lembrando a firmeza e a resistência dos objetos pontiagudos (espetos? estilete?) construídos a partir da liga de vários minérios. Mais que encerrar sintaticamente a estrofe trazendo a informação espacial de onde as libélulas vão espetando (o que espetavam é dito na ordem direta mesmo), o verso 9, "nos alfinetes do sol", retoma o terceiro núcleo semântico, alumínio, por ser o alfinete um objeto em cuja composição entra, se não o alumínio pelo menos um outro minério, quem sabe extraído do quadrilátero? Também o retoma o verso 7, "...broches de jade", pois jade designa exatamente diversos minerais com propriedades comuns, uma delas a cor esverdeada, fundamental para os propósitos paisagísticos do poeta-pintor de Magma (como os sons para o prosador-compositor de São Marcos), tanto assim que em Paisagem já apareceu duas vezes antes, em "verde-aquarela" e em "as libélulas verdes", versos 2 e 6, respectivamente. Mas, como dizíamos, se o verso 9 completa a sintaxe, vai para o ar (não o "de alumínio"!) a semântica, pois alfinete não é instrumento mas sim o lugar onde são espetados os produtos da oficina libelulóide. Ainda trabalhando com os termos alumínio/espetando/alfinete, é possível voltar ao verso 3, "cortam-se em ângulos retos", sendo "cortam-se" semanticamente simétrico a "espetando" e "alfinete" o é aos inominados faca/canivete, dos quais só temos a ação, "cortam-se". Do mesmo modo, de 
"quadrilátero ferrífero" só tínhamos seus efeitos na superfície do poema, mediante o deslizamento de seus significados para a área da Geometria (quadrilátero/ângulos retos/raios/arco) e da agricultura (arrozal/verde-aquarela/canais azuis de água irrigação), depois reconduzidos à significação originária pelo verso 5, "no ar de alumínio".

E o "arrozal"? É esse o núcleo semântico motivador da comutação operada no verso 2 entre "amarela" e "aquarela", por ser o amarelo a cor litigante com o verde nos espaços reservados à cultura do arroz. Tornar-se-ia lugar comum no poema o "verdeamarela", até mesmo por soar como ufanístico, bandeirístico e evocar Verde-Amarelo, grupo modernista cujo manifesto fora publicado em 1929. Guimarães escolhe "aquarela", conservando de "amarela" o segmento final -ela, e mantém o poder cromático-sugestivo de "arrozal". Essas duas operações lingüísticas são suficientes para seu leitor perceber o ausente "amarela". "Verde-aquarela" aparecerá em Sagarana numa sensualíssima (pois comporta todo um simbolismo sexual incrível) passagem de Minha gente, quando Maria Irma e o primo brincam de regar a horta. Nesse conto, para determinar "alfaces", a locução utilizada é precisamente "verde-aquarela", pois as "alfaces" e o "arrozal" possuem, no real, traços semelhantes, levando o autor a fazer uso do mesmo cromático "verde-aquarela".

Nem tão ausente é "verde-amarela" em Paisagem, pois é ele o responsável pelo aquarelamento da primeira estrofe, pincelada ainda de uns "canais azuis de água polida". O último elemento, "polida", abre a via associativa para o "ar de alumínio" do verso seguinte, pois costumam-se polir os vasilhames de alumínio. Já as reverberações produzidas por uma "água polida" (para não dizer "polidez da água"!) refletem-se sobre o ignoto instrumento cortante (que soe brilhante também) do verso anterior, "cortamse...", permitindo-nos preencher com o substantivo faca ou similares a posição deixada vazia na estrofe anterior. Por fim, é a materialidade do arrozal a base da construção da quarta estrofe, pois os caules do arroz fornecem as determinações para o aparecimento da metáfora usada para falar da língua dos sapos, habitantes dos "canais azuis de água", "estilete de uma haste verde / que faz arco (pronto!...)", cuja expressividade já analisamos anteriormente, em especial a contida nos termos "estilete" e "arco".

Já dissemos algo do terceiro núcleo semântico, minerais ("alumínio"). Retornemos à segunda estrofe pelo verso 7, enumeração dos produtos das laboriosas libélulas, "jóias faiscantes, broches de jade", em cuja composição entram minerais, reforçando assim a rede de sentidos criada a partir daquele núcleo. Por fim, observemos, agora, a métrica do verso.

Escandindo-o, temos a vírgula provocando cesura, resultando dois hemistíquios tetrassilábicos,

joi/as/ fais/can/tes

bro/ches/ de/ ja/de

como no verso seguinte: "duplas cruzetas, lindos brinquedos", 


\title{
$\operatorname{lin} / \mathrm{dos} / \mathrm{brin} / \mathrm{que} / \mathrm{dos}$
}

Idêntico procedimento é notado nos versos 19 e 13, com a diferença de trabalhar redondilhas menores: "aberta e visguenta, de um sapo cinzento", "das asas nervadas, reflexos de raios" (verso 13).

\author{
$\mathrm{a} / \mathrm{ber} / \mathrm{ta} \mathrm{e} / \mathrm{vis} / \mathrm{guen} / \mathrm{ta}$ \\ de um/ sa/po/ cin/zen/to (note-se também a aliteração do /t/) \\ das/ a/ sas/ ner/va/das \\ re/fle/xos/ de/ rai/os
}

\section{3- O POEMA SINFÔNICO SÃO MARCOS}

Voltando à poesia do parágrafo inicial do nosso artigo, analisaremos agora o outro procedimento, o trabalho com o estrato fônico da língua.

Como já mencionamos no começo, serão sons e ruídos do mato os guias de Izé após sua cegueira. Consequientemente, ao orquestrar um texto com realizações das virtualidades fonéticas do idioma, Guimarães não só continua a fazer poesia, mas também enriquece a estrutura da sua narrativa, empregando o estrato fônico na preparação do próprio clímax do conto. É necessário reiterar isso, senão estaremos fragmentando o texto, erigindo em entidades autônomas e portadoras de significado próprio aquilo que toma do conjunto (o conto como um todo) parte do seu sentido.

Comecemos pelos "gafanhotos verdes e os gafanhões cinzentos". Nessa construção, a sonoridade é trabalhada mediante a repetição do segmento gafanh-. O procedimento é empregado dentro do mesmo parágrafo na nomeação das árvores, cambuí e camboatã; narração do movimento das aranhas-d'água, corre-correndo; explicitação do que, nos guaxes, interessa ao narrador, namorar o namoro. Ilustra-o ainda a construção da paisagem de uma das ilhas avistadas por Izé: "E nas ilhas, penínsulas, istmos e cabos, multicrescem cem taboqueiras, tabuas, taquaris, taquaras, taquariúbas, taquaratingas e taquaraçus. Outras imbaúbas, mui tupis" (36). Aqui aparecem, além da repetição de taq, o gosto de Guimarães por palavras pertencentes a um mesmo campo semântico, (ilhas, penínsulas, istmos e cabos); aliterações, /t/, /q/, /b/, /r/; rima toante, /a/, /u/; rima externa, "taquaris/tupis". Nos exemplos aduzidos, vemos a repetição do segmento inicial.

De igual modo, notamos em SM a repetição em construções como: "cantos e recantos"; "artes e partes"; "velho velhoso"; "lengas arengas", já encontrados em Magma, "saques e ataques aos carajás de cima", "como as órbitas lentas de um corvo... / Tudo é torvo e pesado" (37). Às vezes assumem o caráter de paronomásia (como no próprio caso de c(t)orvo): "riçava-me pele e pêlos"; "São Marcos e São Manços" (o "manço" - manso contrapondo-se à bravura da oração rezada nesse exato momento e retomando de Magma o poema mais íntimo de São Marcos, Reza Brava, não só pela temática mas em especial por conter a dupla invocação, "e depois a reza brava de São Marcos e São Manso", transformado em São Manço em SM - 38); "vinha vivivendo o visto mas vívando estrelas", com presença da aliteração /v/; "para pegar os peixes mais tolos de todos", 
aparecendo as aliterações /p/ e /t/; "no fresco da relva, na sombra da selva", também duas redondilhas menores:

$\mathrm{no} / \mathrm{fres} / \mathrm{co} / \mathrm{da} / \mathrm{rel} / \mathrm{va}$

$\mathrm{na} / \mathrm{som} / \mathrm{bra} / \mathrm{da} / \mathrm{sel} / \mathrm{va}$

No mesmo rol insere-se o multiclassicável, "silvos e chilros": aliteração /s, ch, s/?; rima interna /il/?; rima toante /i/ /o/? Por fim, o inclassificável particípio de dizer, criado por Tião Tranjão, "dissido": quando pronunciado, ouve-se "de(i)cido", exatamente o que esperam (Tião e o soldado) do Padrinho Antonino.

É a preocupação com os sons da língua a matriz da seqüência e do teor dos mandamentos do negro, elencados por Izé quando passa em frente à casa do negro Mangolô, pois encontramos rima interna na enunciação dos três. Se se trata de mandamentos, tal vocábulo aciona em nossa organização cognitiva um outro campo de associações: os dez mandamentos da sociedade judaica e que Moisés, muito esperta e politicamente, atribuiu a Deus como forma inconteste de legitimação de uma lei social. Não escapou a Guimarães essa conduta cognitiva dos seus leitores, até bem porque ela é despertada pelo discurso narrativo conduzido por ele; não nos dá, via Izé, um decálogo, mas decassílabos, completando, pela métrica, a conexão bíblica:

"Pri/mei/ro:/ to/do/ ne/gro é/ ca/cha/cei/ro;

$\mathrm{Se} / \mathrm{g} u n / d o: /$ to/do/ ne/gro é/ va/ga/bun/do;

Ter/cei/ro:/ to/do/ ne/gro é/ fei/ti/cei/ro." (39)

E, a exemplo daquela reiteração da ornitológica métrica de Minha gente, o narrador constrói um provérbio a partir do mesmo procedimento: "Negro na festa, pau na testa!..." (40), a fim de que o "oco" leitor capte o "eco" (lembrando-nos das vozes dos tucanos de Minha Gente), o som do trecho. Se não captar, "pau na testa", pois mais o narrador não pode fazer, não pode soltar mais nem um "pio", se não se torna exegeta da própria narrativa, o que sabemos ser problema, pois compromete a polissemia e a multissignificância características do texto literário.

Metrificada é ainda a criação da paisagem do mais belo recanto das Três-Águas. O autor vai trabalhar com uma oração intercalada na qual se encontram rimas e as suas tão apreciadas redondilhas menores:

"Mas a grande eritrina, além de bela, calma e não humana, é boa, mui bondosa - com ninhos e cores, açúcares e flores, e cantos e amores - e é uma deusa, portanto".(41)

A seguir, escandimos a oração intercalada, na qual pode ser observada também a rima interna criada entre "açúcares" e a terminação -res das palavras finais dos versos.

$\mathrm{com} / \mathrm{ni} / \mathrm{nhos} / \mathrm{e} / \mathrm{co} / \underline{\mathrm{res}}$

$\mathrm{a} / \mathrm{c} u ́ / \mathrm{ca} / \underline{\mathrm{res}} / \mathrm{e} / \mathrm{flo} / \underline{\mathrm{res}}$ 
Se lembrarmos do convite à castidade feito pelo recanto Renda da Yara e do imperativo "tudo aqui manda pecar e peca" do Vênusberg, não estranharemos a presença agora de vocábulos como "ninhos", "amores" e a muitíssima sugestiva conclusão, "e é uma deusa, portanto", pois qual deusa habitou a paisagem de São Marcos senão Vênus, já que do deus da natureza, Pan, só temos a intenção do narrador de levantar-lhe uma estatueta? Mesmo trabalhando com diversos elementos da geografia regional, o texto não se fragmenta, dada a presença de um subterrâneo tema (sensualidade na natureza), a contribuir para a organicidade do conto. $\mathrm{O}$ cuidado com a unidade pode ser notado também na transição de um acidente geográfico para outro. Desse modo, se no trecho aqui citado são mencionadas as flores, o próximo referente, lagoa, será posto no texto aproveitando-se a idéia de flores. Confiramos:

"Tiro o paletó e me recosto na coraleira. Estou entre o começo do mato e um braço da lagoa, onde, além do retrato invertido de todas as plantas tomando um banho verde no fundo, já há uma movimentação. A face da lago em que bate o sol, toda esfarinhenta, com uma dança de pétalas d'água, vê-se que vem avançando para a outra, a da sombra." (42)

Nossa preocupação agora é com os sons de SM, mas não há como não falar da poesia desse trecho. Primeiro, a abertura triunfal com a "coraleira", onde se encosta Izé. A coraleira é conhecida exatamente por sua riqueza de flores em forma de corais, os quais, provavelmente, são encontrados em lagoas. Em seguida, a lagoa vira um jardim (de igual modo, as penas deixadas pelos magotes de patos que nela pousam produzirá essa jardinagem lacustre), pois nela refletem-se, "retrato invertido", as plantas, dentre elas a coraleira, "tomando um banho verde fundo"! Quanta fusão de imagens e sensações em tão poucas palavras! O banho aqui puxa-nos outros rosianos banhos, acontecidos lá no Magma, no mesmo poema em que o puraquê tinha pensamentos de mil volts:

"No lombo de pedra da cachoeira clara

as águas se ensaboam

antes de saltar." (43)

Parece-nos muito clara a permanência do Guimarães poeta em São Marcos a partir dessa recorrente imagem refrescante da natureza. Em Magma, as próprias águas se ensaboam, sutilmente sugerindo o substantivo "espuma" (assim como "no lombo de pedra" evoca sabão pela via associativa "pedra sabão"), já mobilizado no leitor quando o primeiro verso trabalha com "cachoeira clara" e todos sabemos da existência de espumas em cachoeiras. Agora, em São Marcos, as plantas banham-se verde e fundamente numa ilusão óptica. Retornando às flores, temos depois a consequiência poética desse banho: "uma dança de pétalas d'água". A preposição de assume poderes expressivos muito interessantes. Se o autor usasse pétalas $n a$ água, o texto perderia a dimensão de ajardinamento aquático, ficando-nos apenas as flores das plantas mesmo. Ao usar de, novas pétalas, de fato, brotam do sintagma rosiano, "pétalas d'água", o que, sem dúvida, é uma fina e líquida poesia! Aliás, para irmos mais uma vez ao poema $O$ 
Caboclo d'Água de Magma, também lá há flores: "À sombra dos mangues / que despetalam placas vermelhas", conferindo à água a propriedade de florescer, dada a simbiose entre a vegetação mangue e a água. O gosto pelo florescimento na natureza encontra-se ainda noutro poema de Magma, Amanhecer, do qual destacamos, em itálico, o recorte no idioma de palavras ligadas às cores e às flores (pétalas), além de outras conexões com o já analisado Paisagem, aqui apenas sublinhadas:

\section{"AMANHECER}

Floresce, na orilha da campina,

esguio ipê

de copa metálica e esterlina.

Das mil corolas,

saem vespas, abelhas e besouros,

polvilhados de ouro,

a enxamear no leste, onde vão pousando

nas piritas que piscam nas ladeiras,

e no rio das acácias amarelas.

Dos charcos frios

sobem a caçá-los redes longas,

lentas e rasgadas de neblina.

Nuvens deslizam, despetaladas,

e altas, altas,

garças brancas planam." (44)

Ainda falando de métrica, o caminho domingueiro de Izé é tortuoso, mas retas às vezes são as frases que o constroem, "Entro na capoeira baixa... Saio do capoeirão alto" (45), as duas muito certinhas, contidas na métrica heptassilábica. Àqueles que não se deram ao trabalho da escansão, deveriam notar, pelo menos, a clareza do paralelismo sintático e desconfiar de que por trás dele algo se esconde:

En/tro/ na/ ca/poei/ra/ bai/xa

$\mathrm{Sa} / \mathrm{io} / \mathrm{do} / \mathrm{ca} / \mathrm{poei} / \mathrm{rão} /$ alt/to 
De volta àquele ludismo com a linguagem visto em "gafanhotos verdes e gafanhões cinzentos", mostraremos agora que eles aparecem noutros contos de Sagarana. Duplicase o final dos vocábulos, criando verdadeiros ecos intencionais, dos quais resultam efeitos estéticos interessantíssimos, uma lúdica ecolalia. É o caso de um dos diálogos entre Manuel Fulô e o doutor de Corpo Fechado: "- Não, porque... / - Porque-isquê! / A minha... / - Que-inha? / - Cala a boca! / - Que-oca?" (46). Além do desdobramento porque-isquê, o "que" aparece como pronome nos enunciados subseqüentes, nos quais ocorre a partição de "minha" e "boca". De igual modo, num dos casos de $O$ burrinho pedrês: "- Mas, pulou no cangote do zebu? - Que ote! Que u!..." (47). E o que dizer dos exemplos "exemplares" de Minha gente, "E fui, por inglas de Inglaterras, e marcas de Dinamarcas, e landas de Holanda e Irlanda" (48), em que desgarra e se adianta tanto o início (Inglaterra) quanto o final do substantivo (Dinamarcas/Holanda/Irlanda) próprio, tornando-se independente?

Portanto, o significante exerce sobre Guimarães um fascínio tão grande, chegando às vezes a sobrepujar o significado. Embora saibamos, a partir de Saussure, que o signo lingüístico é significante e significado, logo puro significante é apenas uma abstração, aqui ela é necessária para expressar esse fenômeno da linguagem rosiana. Ficar preso ao significado é perder de vista todo o trabalho verdadeiramente poético com os sons da língua, empreendido pelo autor. O texto soa estranho ao leitor que não o deixar soar!

A construção "gafanhotos verdes e os gafanhões cinzentos" de SM faz ressoar outra eminentemente fônica, desta vez em Corpo Fechado. Referimo-nos a "grilos finfininhos e bezerros fonfonando" (49), cuidadosamente posta após uns versos que falam exatamente de "essa história de phonetica" (50). Temos um autêntico tratado de estilística fônica aqui: aliteração /f/; assonância /i/ e toda sua carga expressiva pela via da harmonia imitativa do som produzido pelos grilos - elevada à última potência no Circo do Miudinho de Ave, Palavra, em que aparece combinada com a repetição da vibrante /r/ em /gr/ e /tr/ - (51); paronomásia, finfininhos e fonfonando; onomatopéia, na forma lexicalizada do verbo fonfona(r)ndo. No caso de gafanhotos/gafanhões, temos a criação das aliterações /g/, /f/ e, depois /t/, "gafanhoto/cinzento". Riqueza maior reside na exploração do domínio morfológico: gaf(a)- funcionaria como radical ao qual se agregariam -nhoto e -nhões como sufixos. Ao operar desse modo com a linguagem, cria duas redondilhas menores, brincando de metrificar suas frases, como já tivemos oportunidade de constatar noutros momentos:

$\mathrm{ga} / \mathrm{fa} / \mathrm{nho} / \mathrm{tos} / \mathrm{ver} / \mathrm{des}$

ga/fa/nhões/ cin/zen/tos

Mas, esse domínio morfológico é tema para outro trabalho que ainda desenvolveremos, considerando os especialíssimos poemas dos bambus e os comentários após eles, verdadeira crítica literária efetivada pelo próprio autor. Só fica a perder aos prefácios de Tutaméia. Numa perspectiva morfofonológica encaixa-se ainda toda a comutação operação em "Pé por pé, pé por si" (52). Introduzir tal tópico nesse artigo seria estendêlo "maismente". Retornaremos a isso, numa próxima publicação. Por ora queremos percorrer os vários movimentos do poema sinfônico das paisagens de SM. Excluiremos do nosso corpus outros fônicos fatos de outros momentos do conto, voltando-nos só para a fauna e flora, pois é esse o nosso foco. 
Ao construir as águas das Três-Águas, uma onda de aliterações compostas a partir da fricativa surda /f/ conjugada à vibrante /r/ ou à lateral /l/ movem-se no texto:

"Pelas frinchas, entre festões franças, descortino, lá embaixo, as águas das Três-Águas. Três? (...) E o buritizal: renques, aléias, arruados de buritis, que avançam pelo atoleiro, frondosos, flexuosos, abanando flabelos, espontando espiques; de todas as alturas e de todas as idades, famílias inteiras, muito unidas: buritis velhuscos, de palmas contorcionadas, buritis-senhoras, e, tocando ventarolas, buritis-meninos" (53).

No caso dos buritis, fica fácil associar à brisa a aliteração, pois é precisamente esse um dos potenciais expressivos da fricativa /f/ (54). Além disso, há no trecho em questão o verbo abanando, e, no final, "tocando ventarolas", reafirmando pelo viés semântico o sentido já introduzido pelo trabalho com o domínio fonológico. A propósito, cabe aqui lembrar o depoimento de Guimarães em sua famosa entrevista ao jornalista alemão Günter Lorenz: "Sou precisamente um escritor que cultiva a idéia antiga, porém sempre moderna, de que o som e o sentido de uma palavra pertencem um ao outro. Vão juntos. A música da língua deve expressar o que a lógica da língua obriga a crer" (55). No entanto, quando voltamos ao início do trecho, a análise não se torna tão facilitada assim, pois na lagoa não há vento e a combinação de /f/ com a vibrante /r/ desfaz o poder sugestivo de sopro, ficando-nos apenas a constatação estatística. Não nos alarmemos, pois, ainda falando dos buritizais, aliterações fundem-se à assonância, "espontando espiques" sem que possa ser encontrada uma razão de cunho harmônico-imitativo. A razão é o gosto do autor em recrear-se com os sons da linguagem, dimensão visível na criança e perdida pelo adulto cartesiano que instituiu a primazia do significado sobre o significante.

O estrato fônico é mobilizado quando da "aquatizagem" dos patos na lagoa. Primeiro temos a forma onomatopaica lexicalizada, "tatalou" para nomear a manobra do pato bravo. É a carga sonora do verbo que leva o autor a empregá-lo em Bicho Mau de Estas Estórias para compor a ruidosa frase do chocalhar da também brava boicininga, "Foi um tatalar - o badalar de um copo de dados - um crepitar, longo tempo - depois esmaecendo, surdo, qual o sacolejar de feijões numa vagem seca", substituido depois pelo ruidoso "matraquear" quando da picada, "Picara duas vezes. E o chocalho matraqueou de novo" (56). Voltando aos patos, só mesmo "tatalar" pode dar conta do altissonante pato bravo, tanto assim que ao falar do próximo "gadinho de asa", "o marrequinho de gravata (...) muito gentil", a pousar na lagoa, o verbo é "aquatiza", desprovido de fonemas ruidosos (embora a vogal /a/ sugira sons fortes, não se combina aqui com consoantes veiculadoras de idéia de golpe, pancada, como /p/, /t/, /d/) e é seguido de um modalizador que combina com a gentileza e o engravatamento do marrequinho, "meigamente". Mas não só o "tatalar" imita o intempestuoso pouso do pato bravo. A frase completa é: "tatalou e caiu, com onda espirrada e fragor de entrudo". Atente-se para a repetição da vibrante $/ r /$, presente ainda na adjetivação do pato, "bravo". Como lá no caso dos buritis, além da seletividade dos fonemas existe a escolha lexical de vocábulos do campo semântico ruído/barulho, no caso, "fragor", como técnicas combinadas para compor um texto musical. E, saindo dos sons, o "espirrar" e "entrudo" retrofletem sobre o parágrafo anterior, quando o autor adjetivava com "esfarinhenta" a lagoa. Isso porque "entrudo" é precisamente um "folguedo 
carnavalesco antigo, que consistia em lançar uns aos outros água, farinha, tinta". Temos então: tinta $\rightarrow$ cores, flores, coraleira; água, $\rightarrow$ lagoa; farinha $\rightarrow$ esfarinhenta. Para maiores vôos, "espirrar" é o verbo empregado antes para falar dos cintilantes efeitos do sol sobre a lagoa, "espirrando asterismos". Mais uma vez notamos a unidade existente entre os vários parágrafos paisagísticos de São Marcos.

Em Magma encontramos no poema Batuque, já musical no próprio título, o melhor exemplo de exploração do estrato fônico:

"Sapateio, patadas, cem pés, em pancadas,

pisando, pelados, aos pulos pesados,

a poeira do chão..." (57)

A combinação da vogal /a/ com as surdas /p/, /t/ e /k/ e a sonora /d/ contribui para aumentar a intensidade do barulho produzido pela dança dos negros. Temos então aliterações $/ \mathrm{p} /$ e /d/ predominando no primeiro e segundo versos e coliteração /t/ /d/ só no primeiro. Como todo batuque é ritmado, o poeta cria cadência e ritmo no segundo verso através da cesura como técnica para construir duas redondilhas menores

$\mathrm{pi} / \mathrm{san} / \mathrm{do} / \mathrm{pe} / \mathrm{la} / \mathrm{dos}$

aos/ $\mathrm{pu} / \mathrm{los} / \mathrm{pe} / \mathrm{sa} / \mathrm{dos}$,

acrescidas de outra no verso seguinte, no qual o forte -ão encerra toda a cadeia melódica do trecho, como a nota mais alta de uma escala musical:

a/ poei/ra/ do/ chão/...

Ao ficar cego, da natureza ao seu redor, o protagonista capta nitidamente os sons: agudiza-se assim o aspecto sinfônico no conto, tantos os cantos a sonorizá-lo. Logo, além do manuseio de fonemas expressivos, a reiteração do sentido da audição contribui para o caráter musical de São Marcos. Ouvem-se então: o canto clássico do patativivo, sonoro já no nome; o soluço das pombas cinzentas; os ensaios de discursos irônicos do aliterado e assonântico araçari e seu taquigrafar nas árvores; os acordes da pedra atirada à lagoa, "bateu musical na água"; o grasnar (com seus barulhentos /gr/ e /a/) dos marrecos; o ruflar (vocábulo onomatopaico, conforme informa-nos o próprio dicionário) da decolagem dos patos; o ribombar (nessa escolha, o gosto por verbos onomatopaicos, a exemplo de "tatalar", pois "bater" não é tão sonoro quanto "ribombar", uma vez que "bom" aproxima-se articulatoriamente das consagradas onomatopéias "bum!" e "pum!") do coração; a clareira agora não é mais um painel colorido como antes, mas "tem boa acústica"; a desalienação do ouvido é tamanha que Izé chega a distinguir o guincho do paturi do coincho do ariri (criam-se: rimas entre, guincho/coincho e paturi/ariri; coliteração /g/, /k/, guincho/çoincho; assonância /a/, /i/ paturi/ariri; aliteração /r/, paturi/ariri. Os fonemas /r/, /a/ e /i/ aparecem no nome de outro pássaro, mencionado antes, o araçari, de tal forma que se colocados lado a lado, araçari/paturi $i$, temos um verdadeiro dueto entre as aves); o "pio labial do joão-pinto", transformado depois numa doçura de sinestesia, "assovio de açúcar" (realiza-se no texto a labialidade do pio do pássaro, dada a seleção das labiais /p/ /b/, já destacadas. Logo, a exemplo dos buritis, o 
autor mobiliza uma palavra, no caso o adjetivo "labial", cujo significado está sendo dito/ouvido pela cadeia sonora do tex to); o cloqueio de uma galinhola; o cochicho do mato, com seu "silvo e chilro", já discutidos noutro momento; a orquestra de violeiros formada pelos "mil bichinhos tocando viola no oco do pau", e coincidentemente o instrumento viola nada mais é que um pau ocado; o sissibilo da cigarra (com toda a carga expressiva da triplicada vogal /i/ e da chiante duplicada /s/, fazendo-nos ouvir a ária do grilo tenor do poema Ironia de Magma: "Um grilo sibila / seu estribilho / de tenor sem sono" (58); o onomatopáico e "eloqüente" "pau-bate-caixa". Para fechar todo esse festival rosiano de ópera ecológica, um maestral comentário do narrador: "Tomo nota". Nota de anotar, para depois recriar, como o fez Guimarães (xará do joão-debarro, mencionado no parágrafo de SM transcrito no começo deste trabalho) pelo sertão, mas também nota de notação musical, já que tudo no texto compõe uma sinfonia (59).

\section{CONCLUSÃo}

Não é novidade para ninguém o fato de a prosa de Guimarães Rosa ser carregada de poesia. Elegemos aqui uma obra do autor, e dentro dela um conto, São Marcos, para explicitar a poesia nele existente, mostrando a continuidade do Magma em Sagarana. Se para alguém e alguma coisa servir nosso Magmarana, que seja para isto: provocar curiosidade e desejo de conhecer Magma.

Encurtamos bastante os aportes e apartes de citações de teóricos do fenômeno literário. Muitas das vezes o desfiar de citações esconde "ceguez" e "surdeira" para o próprio objeto tomado para análise. Que outros façam o contrário entendemos; que não exijam de nós fazer o mesmo é o que esperamos. Se é para lidar com as teorias, ficamos com a Filosofia. Aliás, já filosofando, deparamo-nos com este problema epistemológico na elaboração do trabalho: como apreender, pela despida linguagem lógica, a "plumagem e canto" da poesia? Para solucioná-lo despimo-nos, nalguns momentos, do jargão acadêmico, marca das nossas publicações anteriores, e empenujamo-nos de metáforas para dar conta da análise. Corremos o risco da duplicação de objetos, consoante crítica de Aristóteles à teoria de Platão acerca do mundo das idéias. Mas, qual solução não põe um novo problema?

Dos procedimentos poéticos escolhidos para investigação, associação semântica, métrica, estrato fônico, rimas, temos consciência de a poesia não se resumir a eles. No entanto, foi tal o nosso recorte para ganharmos na extensão da análise e numa exemplificação mais abundante e persuasiva.

Dizíamos, na introdução, que Magma veio em nosso socorro no trabalho com Sagarana. A fina poesia de 1936 foi a grande educadora da nossa sensibilidade, permitindo-nos notar sentidos e beleza onde até então só caçávamos os grandes temas abordados pelo autor, nem sempre encontráveis nos painéis paisagísticos construídos nos contos de Sagarana. Socializar nossos ganhos a partir dessa ressensibilização foi nossa intenção com o presente estudo.

Estas as frases mais nossas apreciadas em todo o Sagarana: "E um vaga-lume lanterneiro, que riscou um psiu de luz" e "De repente, o sabiá! Veio molhar o pio no poço", todas de Minha gente. Fundindo e aplicando-as aos nossos propósitos em Magamarana, podemos concluir de Sagarana: "um psiu de poesia num poço de prosa". 


\section{REFERÊNCIAS BIBLIOGRÁFICAS}

01- DRUMMOND DE ANDRADE, Carlos: Poesia e Prosa. Rio de Janeiro, Nova Aguilar, 1992, 8a ed. p. 15.

02- PRADO, Adélia: Poesia reunida. São Paulo, Siciliano, 1991, p.34.

03- ROSA, J. Guimarães: Sagarana, v. I da Ficção Completa. Rio de Janeiro, Nova Aguilar, 1995, p. 422. Adotaremos, no desenvolvimento do trabalho, a seguinte abreviação para os contos: $B P, \mathrm{O}$ burrinho pedrês; $S A$, Sarapalha; $D U$, Duelo; $M G$, Minha Gente; $S M$, São Marcos; $C F$, Corpo Fechado; $C B$, Conversa de Bois.

04- Idem. Ibidem. P. 361.

05- Idem. Ibidem. P. 376.

06- Sobre a presença desse processo, assim se pronuncia Eduardo F. Coutinho no Prefácio à Ficção Completa de Guimarães, Ed. Nova Aguilar: "Embora seja no campo da sintaxe, ao contrário do que se supõe normalmente, que residem as maiores inovações de GR com relação à linguagem literária (...), a extensão e complexidade do tópico impede que nos detenhamos em uma exemplificação mais detalhada. Optamos, então, pela simples menção a alguns dos processos mais freqüentes empregados neste setor: a enumeração de palavras pertencentes à mesma classe gramatical e ao mesmo campo semântico, que introduz uma ruptura na estrutura sintagmática do discurso, e contribui para uma espécie de neutralização da oposição entre prosa e poesia". (p. 16 Grifos nossos) Se o uso de palavras "pertencentes ao mesmo campo semântico (...) contribui para uma espécie de neutralização da oposição entre prosa e poesia", é porque a associação semântica é um processo mais recorrente na poesia, embora não exclusivo, como dissemos em nossa análise.

$07-$ : Magma. Rio de Janeiro, Nova Fronteira, 1997, p. 92.

08- Para Álvaro Lins, essa racionalidade não significa humanidade. Cf. "Uma grande estréia", Fortuna Crítica, v. I da Ficção Completa, p. 69.

09: Sagarana, p. 281.

10- ANJOS, Augusto dos: Obra Completa. Rio de Janeiro, Nova Aguilar, 1995, p. 203.

11- ROSA, J. Guimarães: Sagarana, p. 284-5.

12- Referimo-nos ao seu artigo $O$ ritmo em "O burrinho pedrês", publicado na Fortuna Crítica da Ficção Completa, v. I, p. 141-148.

13- ROSA, J. Guimarães: Sagarana, p. 354.

14- "A ressonância nasal torna as vogais aptas a exprimir sons velados, prolongados (...) e a sugerir distância, lentidão, moleza, melancolia". Cf. MARTINS, Nilce Sant'anna: Introdução à Estilística: a expressividade na língua portuguesa. São Paulo, taq/EDUSP, 1989, p.32-33. 
15- Correspondência Mário de Andrade \& Manuel Bandeira/organização, introdução e notas Marcos Antonio de Moraes. São Paulo, EDUSP/IEB, 2000. Referimo-nos, em especial, à correspondência de 1922, quando os escritores debatem técnicas de alguns dos poemas de Paulicéia Desvairada e Carnaval.

16- ROSA, J. Guimarães: Sagarana, p. 370.

17- Idem. Ibidem. p. 370.

18- Idem. Magma, p. 96.

$19-$ : Tutaméia, (Ficção Completa, v. II), p. 715.

$20-$ : Sagarana, (Ficção Completa, v. I), p. 367: "E não é sem assim que as palavras têm canto e plumagem".

21- Idem. Magma, p. 97.

22- A expressão encontra-se cunhada em Duelo, na fala do personagem Chico Barqueiro ao descrever para Turíbio os patos que pousam nas margens do rio, mesmo tema de São Marcos: "Conheço esse gadinho de asa!" (p. 309). Estruturalmente estamos diante de um revigoramento da técnica narrativa: trata-se de uma descrição, mas ela é feita não pelo narrador e sim pelo personagem. Logo, não há corte na ação, já que funciona também como diálogo, conversa, prosa entre Chico Barqueiro e Turíbio Todo enquanto fazem a travessia.

23- ROSA, J. Guimarães: Sagarana, p. 371. É nosso o comentário "dia santificado".

24- Idem. Magma, p. 78.

25- Idem. Ibidem, p. 78.

26- Idem. Ibidem, pp. 369-370.

27- MELO NETO, João Cabral: Obra Completa. Rio, Nova Aguilar, 1994, p. 119. Trata-se da segunda estrofe de $O$ Rio, publicado em 1953, portanto após Sagarana. O contexto é este: "Rio menino, eu temia / aquele sede de palha, / grande sede sem fundo / que águas meninas cobiçava". Outro ponto de contato entre os dois escritores é as metáforas marítimas, criadas a partir da extensão e da cor do mar. João Cabral para falar, ainda em $O$ Rio, dos canaviais, latifúndios e usinas da zona da Mata ("À tarde deixo os mares / daquela usina de usinas; vou entrando nos mares /de algumas outras usinas. / Sei que antes esses mares / inúmeros se dividiam / até que um mar mais forte / os mais fracos engolia / (hoje só grandes mares / a Mata inteira dominam).") e Guimarães para falar dos bambus, "Belos, como um mar suspenso, ondulado e parado" (p. 366). João Cabral é mais bem sucedido na sua "maresia", pois consegue fundir também o doce da cana com o salgado do mar.

28- ROSA, J. Guimarães: Magma, p. 45.

29- Idem. Ibidem. p. 62. 
30- Idem. Ibidem. p. 9.56.

31- GONZAGA, Tomás A: Marília de Dirceu. In: A Poesia dos Inconfidentes, Rio, Nova Aguilar, 1996, p. 575.

32- VERÍSSIMO, Érico: Caminhos Cruzados. São Paulo, Círculo do Livro, 1998, p. 8.

33- É este o episódio: Floriano Cambará expõe a Tio Bicho o projeto de escrever um romance sobre a saga das famílias Terra e Cambará. Os dois passam então a discutir o problema da criação literária. É nessa situação que Tio Bicho emite o seguinte parecer crítico, no qual se estabelece a analogia com a pintura: "Já avaliaste os perigos que, do ponto de vista artístico e literário, uma história dessa amplitude envolve? Pintar um mural num paredão do tempo assim tão extenso, palavra, me parece uma tarefa não só difícil como também ingrata. Pensa na vasta comparsaria... Terás de usar ora a pistola automática ora o pincel do miniaturista. Duvido que o efeito de conjunto seja satisfatório". In: O tempo e o vento (O Arquipélago II). São Paulo, Círculo do Livro, 1998, p. 258.

34- ROSA, J. Guimarães. Magma, p. 74.

35- Idem. Magma, pp. 16.18.20.47.50.84.86.90.91.141.

36- ROSA, J. Guimarães: Sagarana, p. 369.

37- Idem. Magma, p. 114.134

38- Idem. Ibidem, p. 112.

39- Idem. Sagarana, p. 362.

40- Idem. Ibidem, p.362.

41- Idem. Ibidem, p. 371.

42- Idem. Ibidem, p. 371.

43- Idem. Magma, p. 92.

44- Idem. Ibidem, p. 140.

45- Idem. Sagarana, p. 366.

46- Idem. Ibidem, p. 397.

47- Idem. Ibidem, p. 216.

48- Idem. Ibidem, p. 341.

49- Idem. Ibidem, p. 385. 
50- Idem. Ibidem, p. 384.

51- ROSA, J. Guimarães: Ave, Palavra. (Ficção Completa, v. II), p. 1156-1157.

52- Idem. Sagarana, p. 376.

53- Idem. Ibidem, p. 369-370.

54- "As labiodentais /f/ e /v/ imitam sopros, podendo ter valor expressivo em vocábulos como voz, vento, fala, fofoca". MARTINS, Nilce Sant'anna: Introdução à estilística: a expressividade na língua portuguesa. São Paulo, taq/EDUSP, 1989, P. 35.

55- "Diálogo com Guimarães Rosa". In: Ficção Completa, v. I, Fortuna Crítica, p. 53.

56- ROSA, J. Guimarães. Estas Estórias, p. 855.858.

57- Idem. Magma, p. 106

58- Idem. Ibidem, p. 84.

59- ROSA, J. Guimarães: Sagarana, p. 373-375. 